\title{
Volcanic Sediment Layer of Mount Samalas 1257 AD Modeling Based on Seismic Data
}

\author{
Suhayat Minardi ${ }^{1 *}$, Teguh Ardianto², Alfina Taurida Alaydrus ${ }^{3}$, and Hiden ${ }^{4}$ \\ ${ }^{1}$ Physics Department, University of Mataram, Jalan Majapahit 62 Mataram 83125, Indonesia \\ ${ }^{2}$ Physics Department, University of Mataram, Jalan Majapahit 62 Mataram 83125, Indonesia \\ ${ }^{3}$ Physics Department, University of Mataram, Jalan Majapahit 62 Mataram 83125, Indonesia \\ ${ }^{4}$ Physics Department, University of Mataram, Jalan Majapahit 62 Mataram 83125, Indonesia
}

( Received: April 15, 2018, Revised: October 27, 2018, Accepted: August 6, 2019 )

\begin{abstract}
Research to determine model of sediment volcanic layer of Mountain Samalas 1257 AD has been conducted in Lombok Island. Modeling based to surface wave velocity data which collect use MASW (multichannel analysis of surface wave) method. The method has applied at 6 locations in southern part relatively and models were made on southern and southeastern of eruption source. Grouping of volcanic layer was based on IBC 2003 (ICC, 2003), TSC, 1998 (Ministry of Public Works and Settlement Government of Republic of Turkey, 1998) criteria. Result of modeling was verified using outcrop at the measurement of seismic area. Volcanic layer groups that detect are C, D, E type which have velocity less than $400 \mathrm{~ms}^{-1}$ and it's thickness less than 50 meters. The volcanic layer group consist of sand, kerikil, clay, batuapung, volcanic ash, and alluvium. All of types of volcanic rocks has founded at all seismic measurement locations with different thickness and composition.
\end{abstract}

Keywords: MASW, model, velocity, volcanic sediment layer group

\section{INTRODUCTION}

There are various kinds of material to be released at a volcanic eruption, such as hot clouds and ash falls, lava flows, and debris flow. Volcano products that fall in a location will be deposited as a volcanic sediment layer (VSL), in the area following the parabolic path before reaching the Earth's surface [1]. This VSL needs to be studied because it relates to the assessment of hazard risk to the surrounding population, infrastructure, aviation and human health $[2,3]$, the modeling of the distribution of risk to assess the danger of population risk and vulnerability [4], and its indicate of pollution to health dangerous level[5].

Mount Samalas which erupted in 1257 released more than $40 \mathrm{~km}^{3}$ of material with an altitude of more than $40 \mathrm{~km}$. As a result of the amount of material released, it caused the Samalas Mountain to collapse and form the Segara Anak caldera in the form of a horseshoe structure on the west side of Mount Rinjani. From the initial survey conducted on the island of Lombok found a spread of sediment phenomena i.e. pumice, volcanic ash, hot clouds, and volcanic ballistics which reaches $35 \mathrm{~m}$ thick. The existence of pumice and lakes, indicates that there has been a terrible eruption, in this case Samalas volcano 1257 AD [6]. This phenomenon has been recorded in the Babad (history notes) Lombok [7], Suwung [8] and Sembalun [9], and Geologically $[10,11]$. Other evidence of massive sulfate anomalous deposits found in the Arctic and Antarctic hemispheres [12] and on the slopes of Mount Merapi which are similar to the sulfate content of the Samalas Volcanic ash in Lombok [13].

\footnotetext{
* Corresponding author

E-mail address: suhayat.minardi@unram.ac.id
} 
In disaster management, precautionary measures, anticipation before a disaster occurs, need to be done, among others, to study the dynamics of subsurface eruption sources, eruption columns, and volcanic products in an area associated with past eruption events, so that it can be predicted when, how much and volcanic reach affected when erupting. For this reason, this study aims to model the volcanic sediment layer based on the seismic characters measured used to MASW (multichannel analysis of surface wave). Product of Mount Samalas eruption is in the form of

- Tefra is a general term for describing all particles emitted from volcanoes at the moment, regardless of size, shape and composition.

- Pyroclasstic Density current (PDCs): a mixture of volcanic particles and hot gases moving rapidly under the influence of gravity.

The tefra is the simplest and most valuable pyroclastic production in physical volcanology, because it leaves the largest source information on the Eruption Source Parameter (ESP), namely: the height of the plume, the mass/volume of the eruption, the rate of eruption, duration of eruption, total grain size distribution [14, 15]. The drop deposits are thinned exponentially or follow the law of rank with distance from ven and plot the logarithm of the thickness of the version of the mean distance from ven [16]. The product of Gunung Samalas 1257 AD has a thick layer of pumice sediment reaching $35 \mathrm{~m}$ towards the Southeast-Northwest and South at 24-35 $\mathrm{km}$ from the eruption source. To the West, at a distance of 15 - $35 \mathrm{~km}$ from the Caldera, the thickness of the sediment is a maximum of $6 \mathrm{~m}$ and is generally in the form of an expanse of limestone granules covering the topography. In general, volcanic sediment outcrops were found in the form of layers intermittent: volcanic ash, sand, ignimbrid and pumice.

\section{METHOD}

This study aims to model the volcanic sediment layer based on the seismic characters measured by the MASW (multichannel analysis of surface wave).

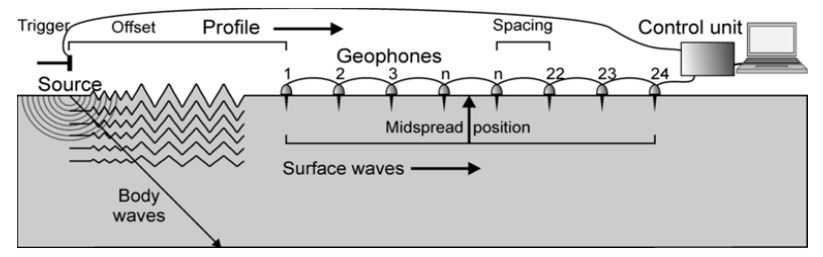

Figure 1. The principle of measurement MASW [17]

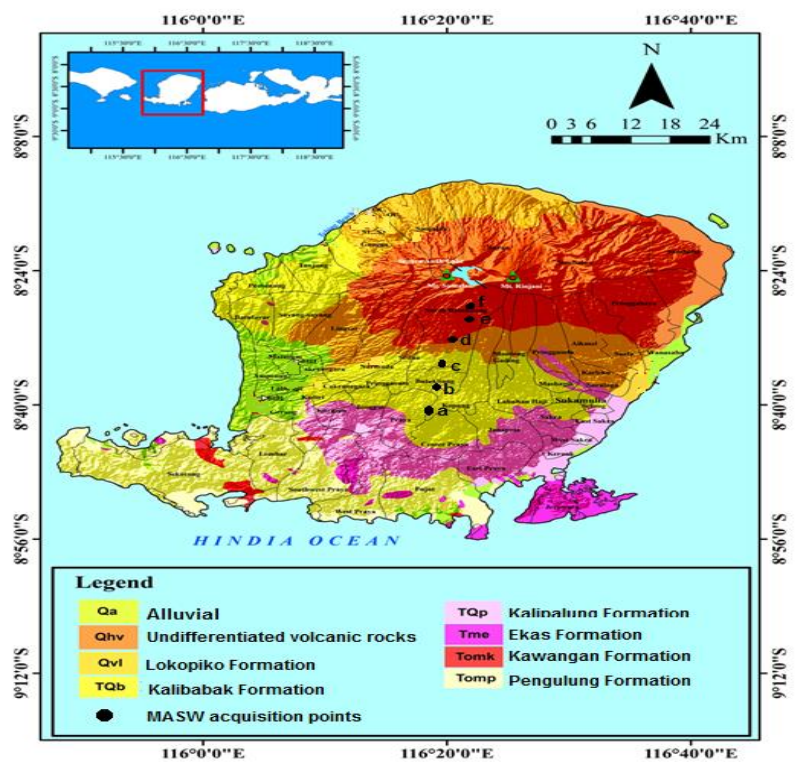

Figure 2. Location of data acqusition

The equipment that used in the seismic measurement with the MASW method is PASI 24 channel seismograph and its accessories (Figure 3). The software used to process data and modeling is Geopsy-Dinver and SeisImager

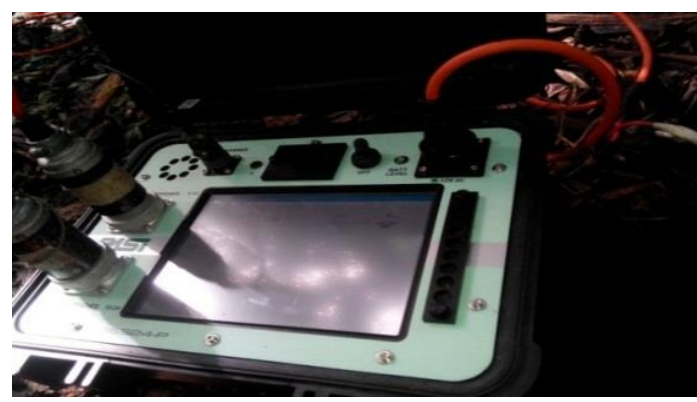

(a)

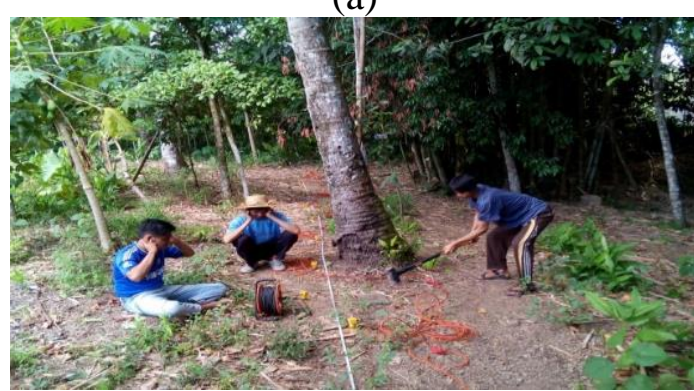

(b)

Figure 3. (a) PASI 24 seismographs; (b) the wave generation with a hammer blow

The research stages which consist of acquisition, processing, and data interpretation stages will produce the output which is the next step input as shown in Figure 4. Data processing used to inversion method to produce velocity of shear wave as a function of depth. 


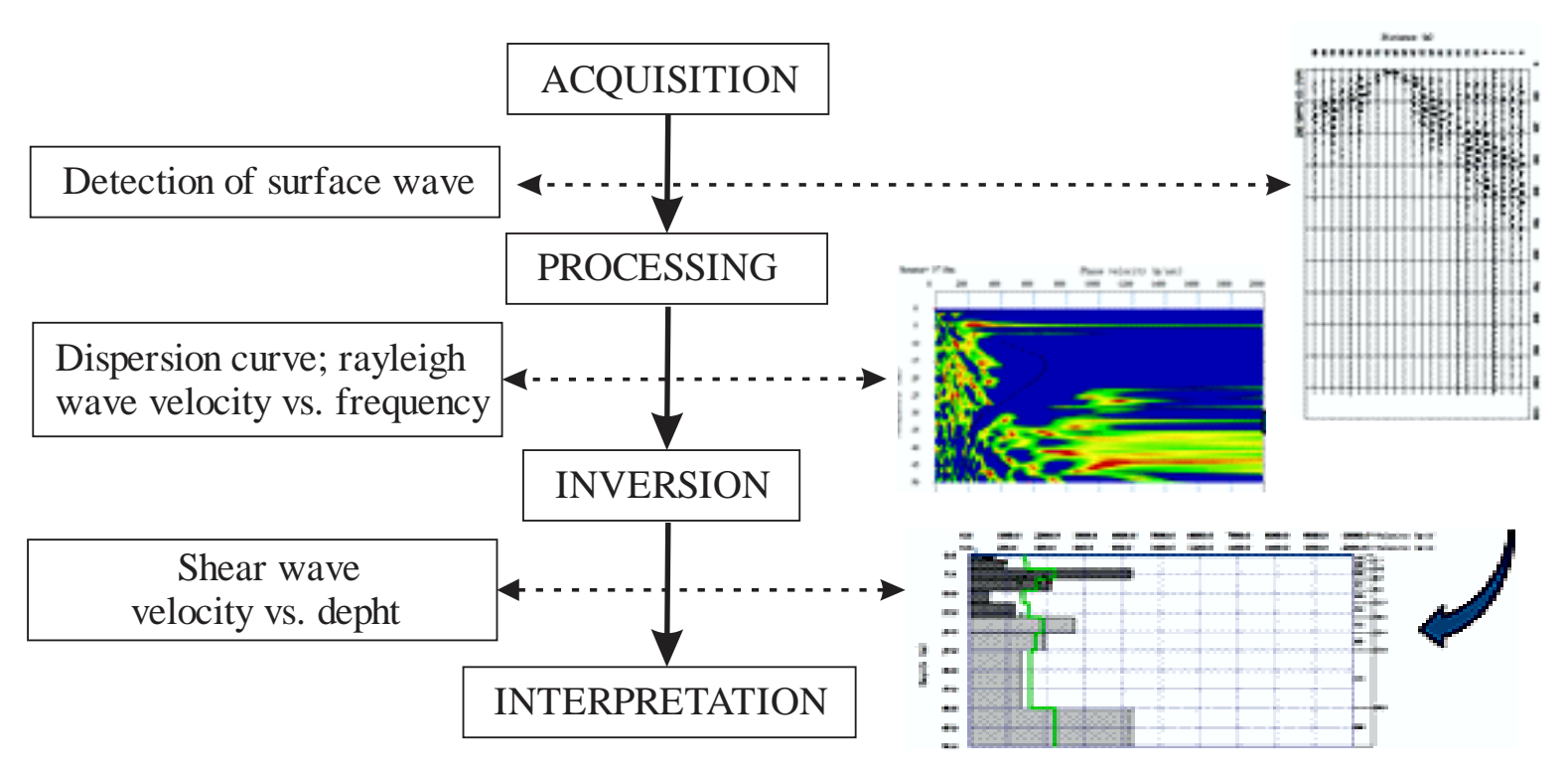

Figure 4. Survey stages and MASW data processing

\section{RESULTS AND DISCUSSION}

Seismic data collection with the MASW method is carried out in 6 (six) locations located south of the eruption source. This data acquisition is intended to detect surface waves after the wave source is generated. The recording results are in the form of recording the arrival time of the wave at each receiver (geophone). After experiencing a series of processing stages and inversion modeling, a velocity of shear wave is obtained as a function of depth. One example of inversion modeling results on the location of Benang Kelambu as presented in Figure 5.

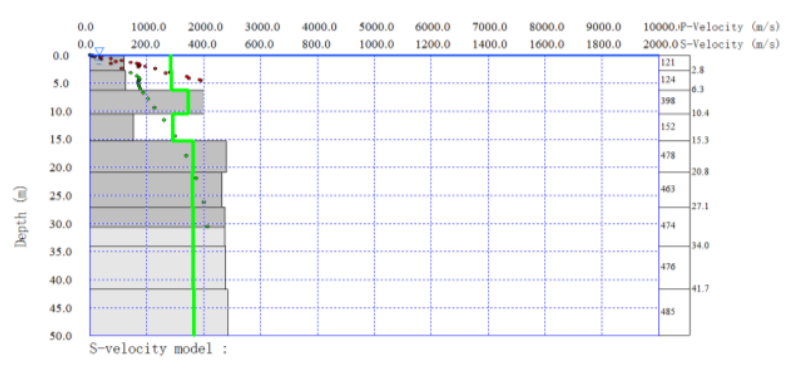

Figure 5. Results of inversion of MASW measurements in Benang Kelambu

The results of data interpretation are done by grouping rocks based on their velocity of shear wave with the criteria of IBC 2003 (ICC, 2003), TSC, 1998 (Ministry of Public Works and Settlement Government of Republic of Turkey, 1998). For rocks in the Benang Kelambu location the results of the interpretation are presented in Table 1 . The results of these interpretations contain lithological description, depth and classification based on the velocity of shear wave. The same is done for the other 5 measurement locations.

Table 1. inversion results and lithological description of Benang Kelambu locations

\begin{tabular}{|c|c|c|c|}
\hline $\begin{array}{c}\mathbf{V}_{\mathbf{s}} \\
(\mathbf{m} / \mathbf{s})\end{array}$ & $\begin{array}{c}\text { Depth } \\
\text { (m) }\end{array}$ & Class & Descriptionof lithologyi \\
\hline 226 & 2.80 & \multirow{2}{*}{ D } & \multirow{2}{*}{$\begin{array}{l}\text { Clays, classtic sand, and } \\
\text { inserted grain pumice }\end{array}$} \\
\hline 234 & 6.30 & & \\
\hline 424 & 10.40 & \multirow{7}{*}{ C } & \multirow{7}{*}{$\begin{array}{l}\text { High density rock and } \\
\text { soft rock: highly } \\
\text { weathered soft } \\
\text { metamorphic rocks and } \\
\text { cemented sedimentary } \\
\text { rocks with discontinue } \\
\text { planes. Medium dense } \\
\text { sand and gravel }\end{array}$} \\
\hline 368 & 15.30 & & \\
\hline 364 & 20.80 & & \\
\hline 391 & 27.10 & & \\
\hline 403 & 34.00 & & \\
\hline 396 & 41.70 & & \\
\hline 370 & & & \\
\hline
\end{tabular}

Modeling is done by correlating rock layers on three cross section that lead south and southeast. Correlation is based on the results of grouping / classification of rock groups and their depth location. The measurement location and height contour can be seen in Figure 6. 

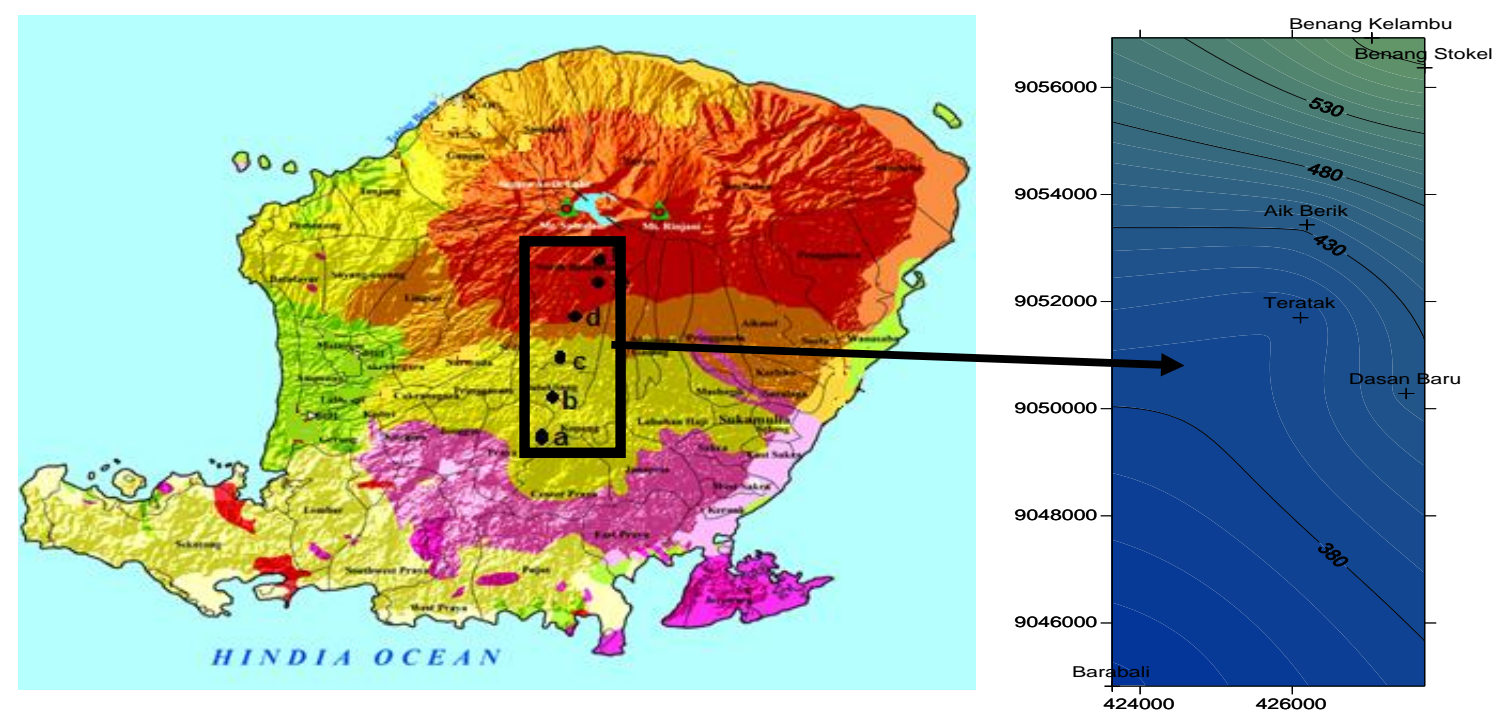

Figure 6. Location of seismic data acquisition ang its topographic contour

Cross section of Benang Kelambu - Benang Stokel has a length of $0.9 \mathrm{~km}$ and has a relative northwest - southeast direction, as shown in Figure 7 on the side. The lithology system consists of soil (Class E), alluvial, loose sand and soft clay (Class D), and finally layers of sand, gravel and rigid clay (Class
C). The sequence of layers from bottom to top are respectively classes $\mathrm{C}, \mathrm{D}$, and $\mathrm{E}$. Based on the order of position, the class $\mathrm{C}$ layer is the oldest layer, followed by Class D layer, and the Class E layer is the youngest layer.
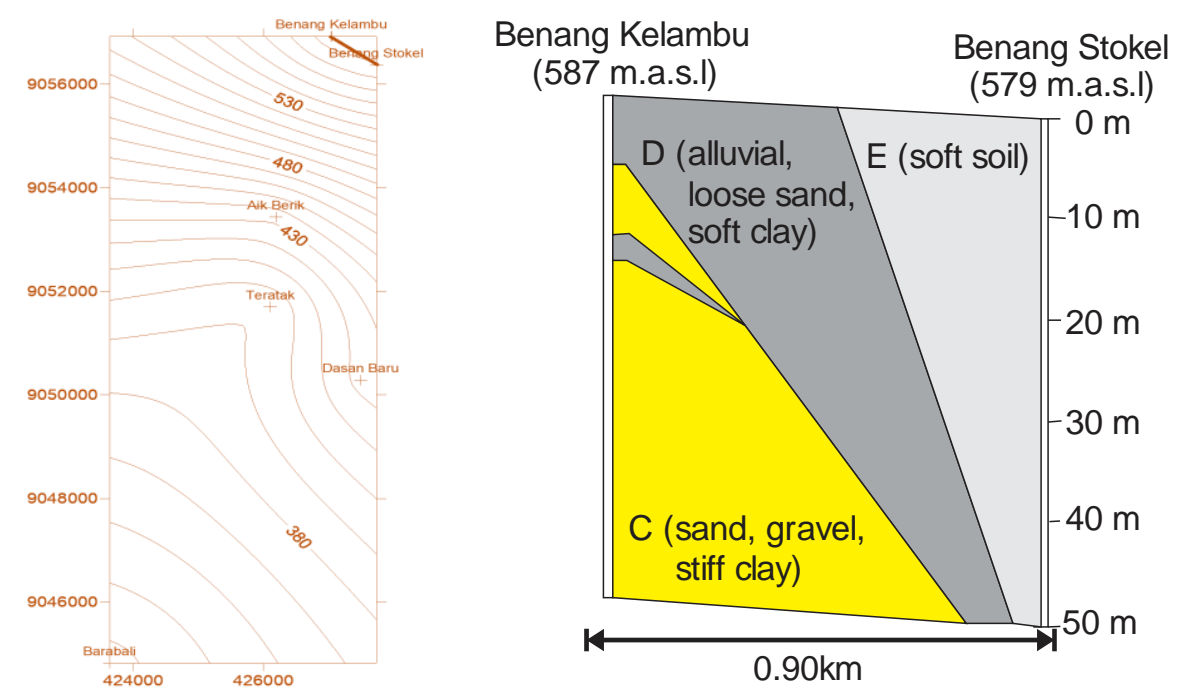

Figure 7. Model of volcanic sediment layer along Benang Kelambu - Benang Stokel cross section 

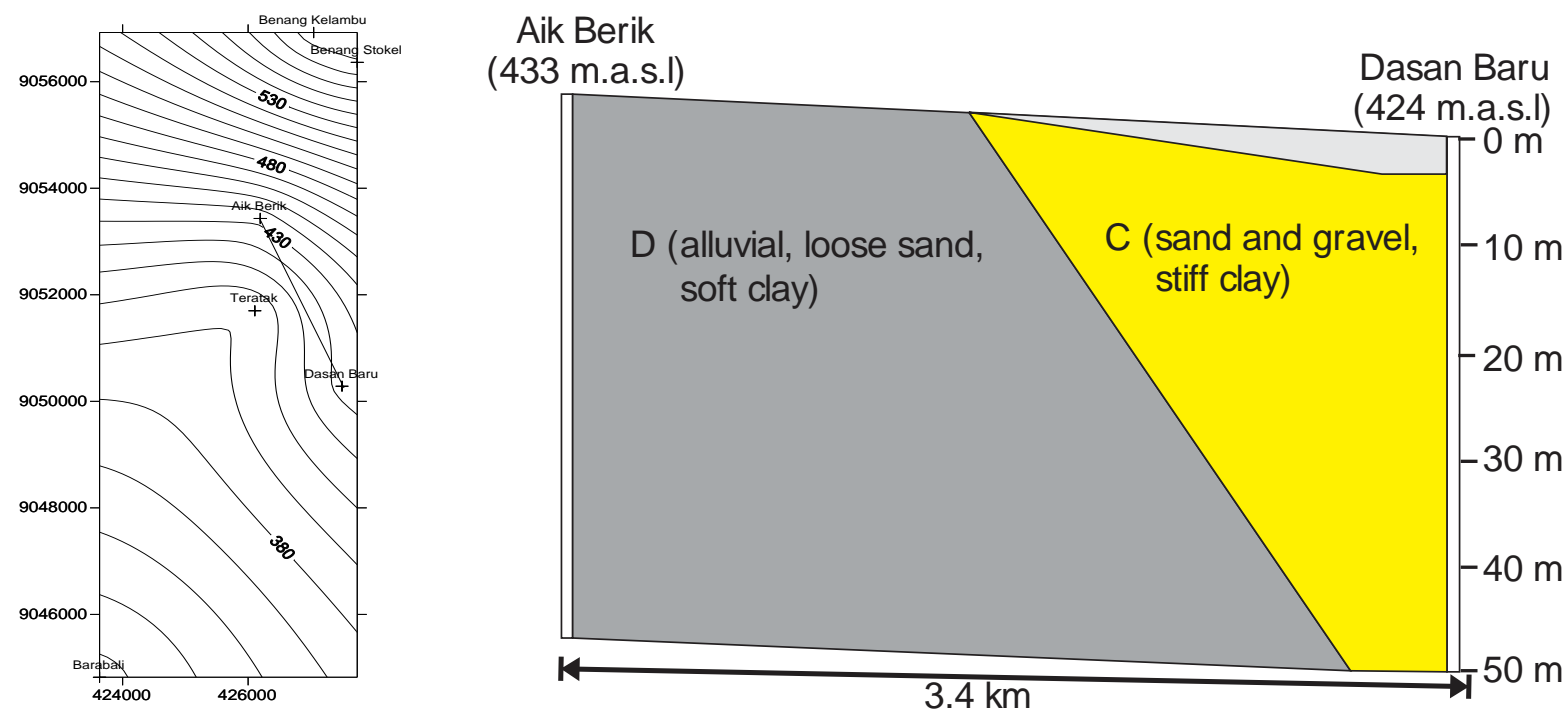

Figure 8. Model of volcanic sediment layer along Aik Berik - Dasan Baru cross section

This cross section has a length of about $3.4 \mathrm{~km}$ and is relatively northwest - southeast. Sediment layer Class D, C, and a few Class E were found in this cross section. This near surface layer corresponds to rock outcrops found in Dasan Baru as presented in Figure 10 (a).
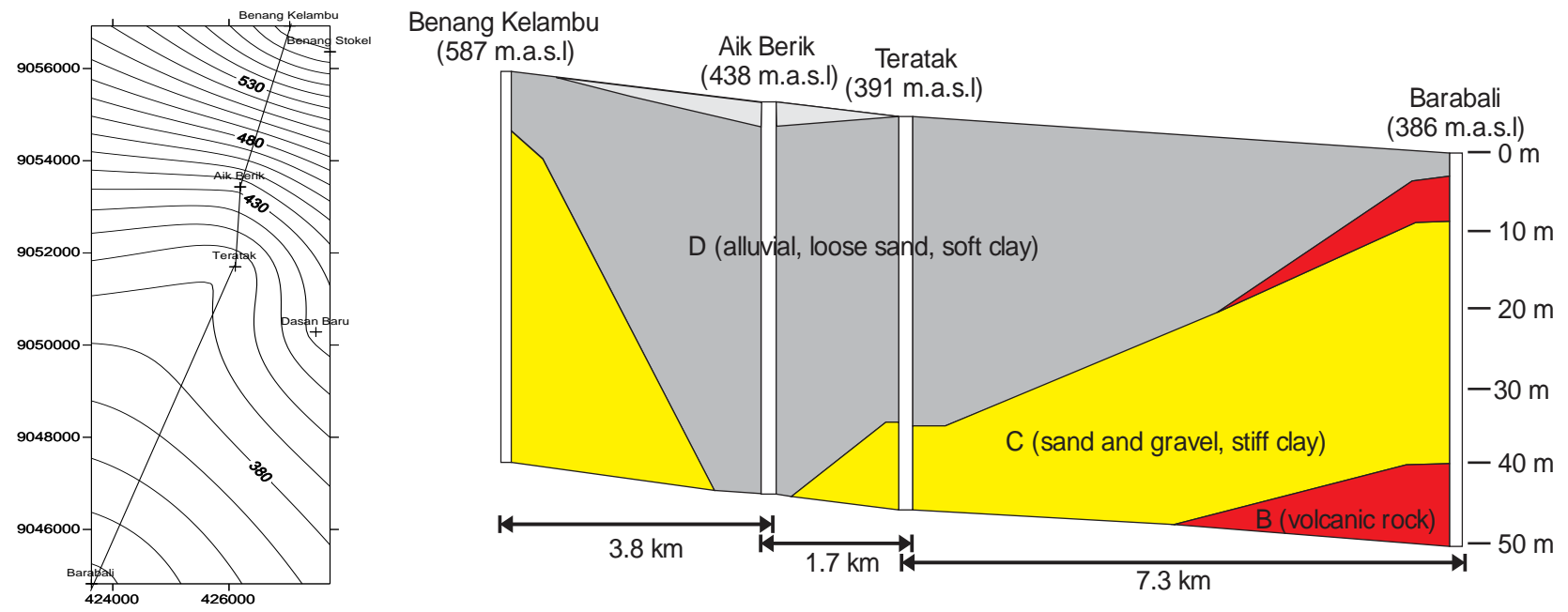

Figure 9. Model of volcanic sediment layer along Benang Kelambu - Aik Berik - Teratak - Barabali cross section

Modeling on the cross section which is relative to North - South with a length of about $12.5 \mathrm{~km}$. This cross section is through Benang Kelambu - Aik Berik - Teratak - Barabali, as shown in Figure 9. On this path there is a rock layer of Class B (Volcanic Ash), Class C (Sand and gravel, clay), Class D (Alluvial, loose sand, silt) and a layer of Class E (soil). In the near surface outcrop as presented in Figure 10 (b) in the Barabali location the rock layer is the same as the modeling result. 


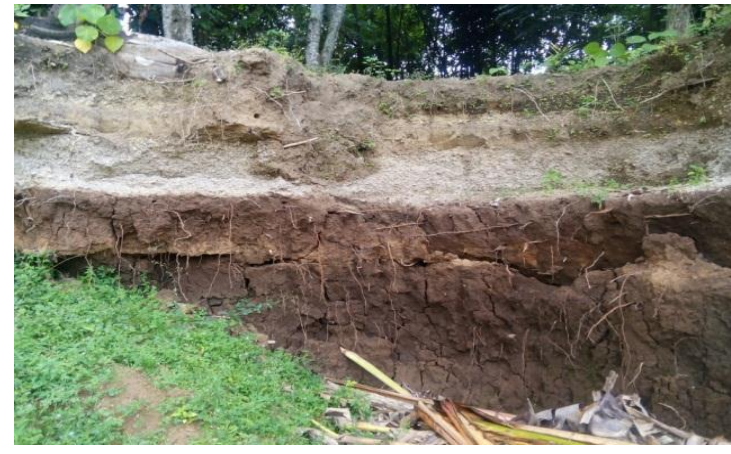

(a)

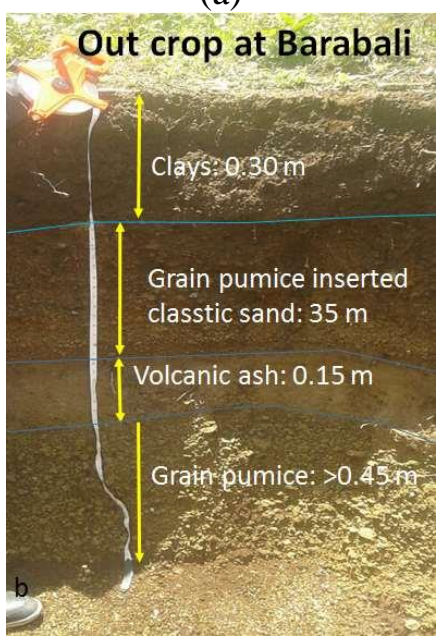

(b)

Figure 10. Outcrop in the location of (a) Dasan Baru and (b) Barabali

\section{CONCLUSION}

Based on the modeling of volcanic sediment layer, distribution to the south is found in class B rock, class $\mathrm{C}$, class $\mathrm{D}$, and class $\mathrm{E}$ and in the southeast direction class $\mathrm{C}$, class D, and class $\mathrm{E}$ are found.

\section{ACKNOWLEDGMENT}

I want to say thank you to Directorate of Research and Community Service, Directorate General of Research and Development Strengthening. Ministry of Research, Technology and Higher Education (DPRM-KEMENRISTEKDIKTI) which is funded this research with the Research Contract Number: 074/SP2H/ LT/DPRM/IV/2017

\section{REFERENCES}

[1] Ibargüengoitia, Alatorre-M.A., DelgadoGranados, H., Dingwell, D.B., 2012. Hazard map for volcanic ballistic impacts at Popocatépetl volcano (Mexico). Bull. Volcanol. Vol. 74: 2155-2169

[2] Kandlbauer, j., Steven N. Carey and R. Stephen J. Sparks, 2013, The 1815 Tambora ash fall: implications for transport and deposition of distal ash on land and in the deep sea, Bull Volcanol, vol.75:708

[3] Maeno, Fukashi, Nakada, Setsuya Nagai, Kozono,M., Tomofumi, 2013, Ballistic ejecta and eruption condition of the vulcanian explosion of Shinmoedake volcano, Kyushu, Japan on 1 February 2011.Earth Planets Space, 65:609-621.

[4] Connor CB, Hill BE, Winfrey B, Franklin NM, La Femina PC, 2001, Estimation of volcanic hazards from tephra fallout. Natural Hazards Rev vol. 2:33-42.

[5] Moore KR, Duffell H, Nicholl A, Searl A., 2002, Monitoring of airborne particulate matter during the eruption of Soufrire Hills Volcano, Montserrat. In: Druitt TH, Kokelaar BP (eds) The eruption of Soufrire Hills Volcano, Montserrat, from 1995 to 1999. Memoir, Geological Society, London, pp 557-566.

[6] Lavigne, F, Degeai, J-p, Komorowski, J-c, Guillet, S, Robert, V, Lahite, P, Oppenheimer, C, Stofflel, M, Vidal, C.M, Surono, Pratomo, I, Waser, P, Hajdas, I, Hadmoko, D.S., and de Belizal, E, 2013, "Source of the Great A.D.1257 Mystery Eruption Unveiled, Samalas Volcano, Rinjani Volcanic Complex, Indonesia" PNAS.

[7] Wacana, L. G., 1979, Babad-Lombok, Departemen Pendidikan dan Kebudayaan Proyek Penerbitan Buku Bacaan san Sastra Indonesia dan Daerah. Jakarta.

[8] Anonim, 2015, Babad Suwung, personal comunication

[9] Purnia, 2015, Penghiling-hiling, Babad Sembalun, personal comunication

[10] Nasution A, Takada A., Udibowo, Widarto D., and Hutasoit L., 2010, Rinjani and Propok Volcanics as a Heat Sources of Geothermal Prospects from Eastern Lombok, Indonesia, Jurnal Geoaplika. Vol. 5(1): 1 - 9.

[11] Mangga, S.A, Atmawinata, S, Hermanto, B, Setyonugraho, B dan Amin, T. C. 1994. "Peta Geologi_lombok,." Pusat Penelitian Dan Pengembangan Geologi, Bandung

[12] Oppenheimer, Clive, 2003, Ice core and palaeoclimatic evidence for the timing and nature of the great mid-13th century volcanic eruption. International Journal of Climatology. Vol. 23(4): $417-426$.

[13] Vidal, C.M., Komorowski, J.C., Métrich, N, Pratomo, I., Kartadinata,N, Prambada, O, Michel,A, Carazzo, G., Lavigne, F., Rodysil, Fontijn, K., \& Surono, 2015, Dynamics of the major plinian eruption of Samalas in 1257 A.D. (Lombok, Indonesia) Céline M. Bull Volcanol.Vol. 77(73). 
[14] Bonadonna, C., Ernst, G.G.J., Sparks, R.S.J., 1998, Thickness variations and volume estimates of tephra fall deposits: The importance of particle Reynolds number, Journal of Volcanology and Geothermal Res., vol 81(3-4): 173-187.

[15] Bonadonna, C., Biass, S., Costa, A., 2015, Physical characterization of explosive volcanic eruptions based on tephra deposits: Propagation of uncertainties and sensitivity analysis, J.
Volcanology and Geothermal Res.vol. 296: 80100

[16] Pyle, DM.,1989, The thickness, volume and grainsize of tephra fall deposits, Bull Volcanol,vol. 51:1-15

[17] PARK CHOON B., RICHARD D. MILLER, JIANGHAI XIA, AND JULIAN IVANOV, 2007,: Multichannel analysis of surface waves (MASW) - active and passive methods, Kansas Geological Survey, Lawrence, USA , THE LEADING EDGE JANUARY (2007) 